\title{
Design and Development of Semi-Direct Copra Dryer for Flat Terrain
}

\author{
Mencius B. Lesidan ${ }^{1}$
}

\begin{abstract}
The study was conducted to design and develop a semi-direct dryer for flat terrain. The components of the dryer were the drying bed, plenum chamber, tunnel and firing chamber. It has a capacity of 2,000 nuts and the husks from the nuts were used as fuel for the dryer. The means of the average drying temperature on the front, middle and rear portions of the drying platform were $56.5^{\circ} \mathrm{C}, 58.2^{\circ} \mathrm{C}$, and $58.4^{\circ} \mathrm{C}$, respectively. The average time of drying in bringing down the moisture content of the copra from $50 \%$ to $12 \%$ wet basis was 24 hours using $66.30 \%$ of the husks. As of October, the total cost of the dryer with shed was P 62,000.00 and the computed break-even cost was P 1.82/kg. This dryer provides coconut farmers an alternative to existing dryers particularly the semi-direct since it is only suitable for rolling terrain.
\end{abstract}

Key words: Design, development, semi-direct copra dryer, terrain, copra

\section{Introduction}

\section{Importance of the Study}

The "tapahan" dryer is commonly used by the coconut farmers in the Philippines in copra processing. According to Raghavan (2010), the basic features which make the "tapahan" dryer preferred by farmers are: high thermal efficiency of the dryer, low cost of construction, simplicity of the design and low cost of fuel. However, de Castro (1978) stated that copra made from "tapahan" are most often unevenly dried and usually blackened by soot. Sudaria (1993) also mentioned there is a high probability of the "tapahan" together with the copra getting burned because the firing place is directly under the drying bed.

Sudaria (1993) developed a semi-direct type copra dryer. It has the same heating principle as the "tapahan" dryer but the firing chamber is away from the drying platform connected by a tunnel. It was also cheap using only materials available on the farm such as coconut lumber, coconut fronds and bamboo. However, this dryer is only suitable when constructed on rolling terrain. Problems occur in the construction if the terrain is flat and the water table level is high. The firing place reaches the water table and the slope of the tunnel connecting the firing place to the plenum chamber is quite difficult to excavate resulting in an uneven heat distribution on the drying bed. There are developed copra dryers suitable for flat terrain particularly indirect dryers. The problems of this dryer were low thermal efficiency and very expensive (Escalante, et al. 1977). This dryer was designed to provide farmers an alternative to traditional and existing dryers particularly the semi-direct dryer.

\section{Objectives of the Study}

The general objective of the study was to design and develop a semi-direct dryer, evaluate the performance and determine the break-even cost of the dryer for flat terrain.

\footnotetext{
${ }^{1}$ National Coconut Research Center - Visayas, Visayas State University, Visca, Baybay City, Leyte, 6521-A. Email: mencius.lesidan@gmail.com
} 


\section{Materials and Methods}

\section{Design Consideration}

The following criteria were formulated based on the information collected from the coconut farmers, existing copra dryers, and personal experience to develop an up to standard copra dryer: a. cost should not be higher than any alternative dryers for flat terrain, b. construction should not require special tools, c. easy to use and maintain, the lifespan of the essential dryer components should be at least five years, a dryer can accommodate 2,000 coconuts per batch, heat distribution on the drying platform must be comparatively equal, thermal efficiency of not less than $12 \%$, fuel usage is lower than $90 \%$ of the husks of nuts loaded and the performance is comparable to the existing semi-direct dryer.

\section{Design, Construction and Testing}

The semi-direct dryer for rolling terrain of Sudaria (1993) was the basis of the design. Modifications were made for it to be suitable for flat terrain. The design of the dryer was prepared using AutoCAD 2016. The dryer was constructed at Visayas State University, Visca, Baybay City, Leyte. The materials used in constructing the dryer were bamboo slats, hollow blocks, cement, sand, gravel, deformed round bars, and lumber. The components of the dryer were the drying bed, plenum chamber, tunnel and firing chamber.

Drying Bed: It had a dimension of $320 \mathrm{~cm} \mathrm{x}$ $240 \mathrm{~cm} \mathrm{x} 70 \mathrm{~cm}$. Bamboo slats were used in the construction of the drying platform and laid 2 to $3 \mathrm{~cm}$ between slats. Beneath the bamboo slats were nine $5.08 \mathrm{~cm} \times 15.24 \mathrm{~cm}$ lumber. The drying bed was elevated $215 \mathrm{~cm}$ above the ground and stairs were provided on the perimeter of the drying platform. The sides of the drying bed were made from $10.16 \mathrm{~cm}$ x $20.32 \mathrm{~cm}$ concrete hollow blocks supported by $10 \mathrm{~mm}$ reinforcing deformed round bars. The drying bed has a pathway of $75 \mathrm{~cm}$ x $75 \mathrm{~cm}$ near the center.

Plenum Chamber: It was made of compacted soil and has a spoon-like design with a parabolic curve with $1 \mathrm{~m}$ center depth from the drying platform.

Tunnel: It had an inner dimension of $55 \mathrm{~cm}$ x $55 \mathrm{~cm}$ with $10 \%$ inclination. It was made from $10.16 \mathrm{~cm} \times 20.32 \mathrm{~cm}$ hollow a blocks reinforced with $10 \mathrm{~mm}$ deformed round bars. The tunnel has a wide opening with dimension of $150 \mathrm{~cm} \mathrm{x}$ $240 \mathrm{~cm}$ near the drying platform. The tunnel has a total length of $300 \mathrm{~cm}$.

Firing Chamber: The firing chamber was connected to the tunnel. It has a dimension of $80 \mathrm{~cm} \times 190 \mathrm{~cm}$.

A preliminary test was done after the construction. The dryer was tested without load using dry coconut husk as fuel. Laboratory thermometers were placed on the front, middle and rear portions of the drying platform. The temperature was monitored for 2 hours. The dryer was further modified and tested until the temperature on the different portions of the drying platform was comparatively even and ready for final evaluation. Figure 1 shows the orthographic views of the dryer.

\section{Preparation of Coconuts}

Mature nuts of Baybay Tall variety were used in this study. The coconuts were de-husked using a traditional dehusker. The removed husks were kept in a dry place and used as fuel for the dryer. The shell was cracked open by using a machete resulting in two almost equal "cups". The coconut water was drained off and the "cups" were dried with the meat still attached to the shell. The "cups" were immediately loaded on the drying platform with the first layer in a vertical position. The succeeding layers were placed in an inclining position and the topmost layer was placed with the kernel facing down.

\section{Performance Evaluation}

Twelve samples were collected randomly from the pile. Each sample was weighed using a digital weighing scale to determine the initial weight of the meat with the shell. The samples were labeled and placed on the bottom and top portion of the pile on the different location (right and left side of front, middle and back portion) of the drying platform. Laboratory thermometers were placed near the samples to determine the drying temperature and outside the dryer to determine the ambient temperature.

During the drying process, the weight of the samples and temperature were measured and recorded at an hourly interval. A constant feeding rate of 9 to 11 husks per 10 minutes of drying was observed to control and regulate the drying temperature. The drying was accomplished after 3 stages, i.e. 8 to 9 hours 


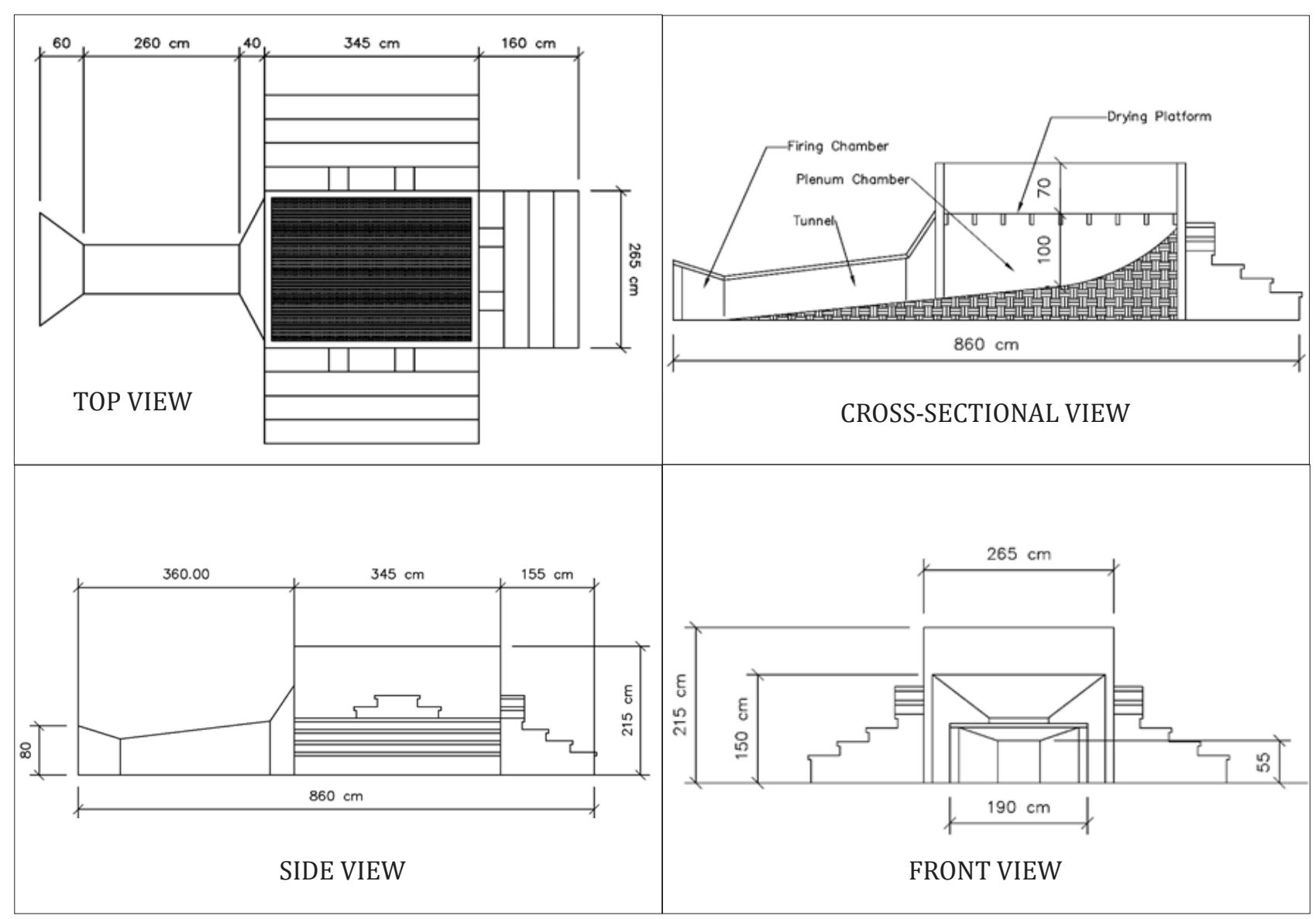

Figure 1. Orthographic view of the dryer

of continuous firing at daytime and allowed to cool-off during the night. At the 3rd stage of drying, the shell and meat were separated using a scooper when the shell and meat were partially detached. The weight of the shell was measured. The drying was stopped when the copra had reached a moisture content of $12 \%$, the moisture content level where local coconut farmers sold their copra to village traders at a discounted price. This is referred to as the "pasa" system.

The drying was replicated thrice using 2,000 nuts per replication. The total drying time was recorded. The used coconut husks were counted to determine fuel consumption. The appearance of the copra produced was observed. The temperature difference on the different portion of the dryer was compared using oneway analysis of variance.

\section{Estimation of Drying Efficiency}

The drying efficiency of the semi-direct dryer was estimated using equation 1.

\section{Eqn. 1}

Thermal Efficiency $\left(\eta_{t}\right)=\frac{\varphi \lambda\left(M_{o}-M_{f}\right)}{W C\left(100-M_{o}\right)} \times 100$

Where, Mo = initial moisture content of coconut ( $\%$, wet basis), $\mathrm{Mf}=$ final moisture content ( $\%$, wet basis), $\varphi=$ quantity of the final dried product at Mf moisture content $(\mathrm{kg})$, $\lambda=$ latent heat of vaporization of water in $\mathrm{kcal} / \mathrm{kg}$., $\mathrm{W}=$ quantity of fuel used (kg), and $\mathrm{C}=$ calorific value of fuel used ( $\mathrm{kcal} / \mathrm{kg}$ ) (Sing et al., 1999).

\section{Determination of Break-even Cost}

In determining the break-even-cost (BEC), the procedure discussed by Henderson et al. (1976) was used. It considered both the cost of the dryer and its output. BEC was computed in terms of amount per kilogram of copra. 


\section{RESULTS AND DISCUSSION}

\section{Semi-direct Dryer for Flat Terrain}

The components of the semi-direct dryer were the drying bed, plenum chamber, tunnel and firing chamber. The drying bed had a volume of $320 \mathrm{~cm} \times 240 \mathrm{~cm} \times 70 \mathrm{~cm}$ with a capacity of 2,000 nuts. A passageway was made on the drying bed to ease the maintenance of the dryer. The firing chamber was $300 \mathrm{~cm}$ away from the drying platform connected by a tunnel. The tunnel connects the plenum chamber and the firing chamber and facilitates the flow of the hot air. The size of the tunnel was $55 \mathrm{~cm} \times 55 \mathrm{~cm}$ for the first $260 \mathrm{~cm}$ and the remaining $40 \mathrm{~cm}$ was an enlarged cross-section going to the drying platform which regulates the airflow to have an equal distribution of heat throughout the drying bed. It had an inclination of $10 \%$ which ensures that the burned fuel from the firing chamber is not blown into the plenum chamber where it could burn the copra. The plenum chamber had a spoon-like design with a $100 \mathrm{~cm}$ center depth from the drying platform. The spoon-like design of the plenum chamber allows the dryer to evenly distribute the hot air including the corners of the drying platform which results to an equally cooked copra. A shed was constructed for continuous drying throughout the rainy season. Figure 2 shows the semi-direct dryer for flat terrain.

\section{Development of the Semi-direct Dryer}

The semi-direct dryer of Sudaria (1993) was modified particularly the inclination of the tunnel. Sudaria (1993) mentioned that the tunnel inclination for semi-direct dryer would be around 20 percent. However, the dimension was not suitable for the flat terrain. The height of the drying bed is $260 \mathrm{~cm}$ which is difficult when loading and unloading the copra. The tunnel inclination was modified to 10 percent to achieve a feasible height of $215 \mathrm{~cm}$ of the drying bed. Other dimensions i.e. volume of the drying bed, tunnel size, and firing chamber size were followed.

A preliminary test revealed that the heat distribution on the drying platform was uneven. The temperature on the front section of the drying platform was very high compared to the temperature on the middle and back sections of the drying platform. The temperature difference between the front and back section of the drying bed is about $15^{\circ} \mathrm{C}$ to $20^{\circ} \mathrm{C}$. According to Sudaria (1993), the size and inclination of the tunnel affect the heat distribution on the drying platform. The total length of the tunnel was 300 $\mathrm{cm}$. It was divided into two sections. From the firing chamber, for the length of $260 \mathrm{~cm}$ the cross section of the tunnel was $75 \mathrm{~cm} \mathrm{x} 75 \mathrm{~cm}$. The remaining $80 \mathrm{~cm}$ was an enlarged cross section going to the drying platform. By decreasing the

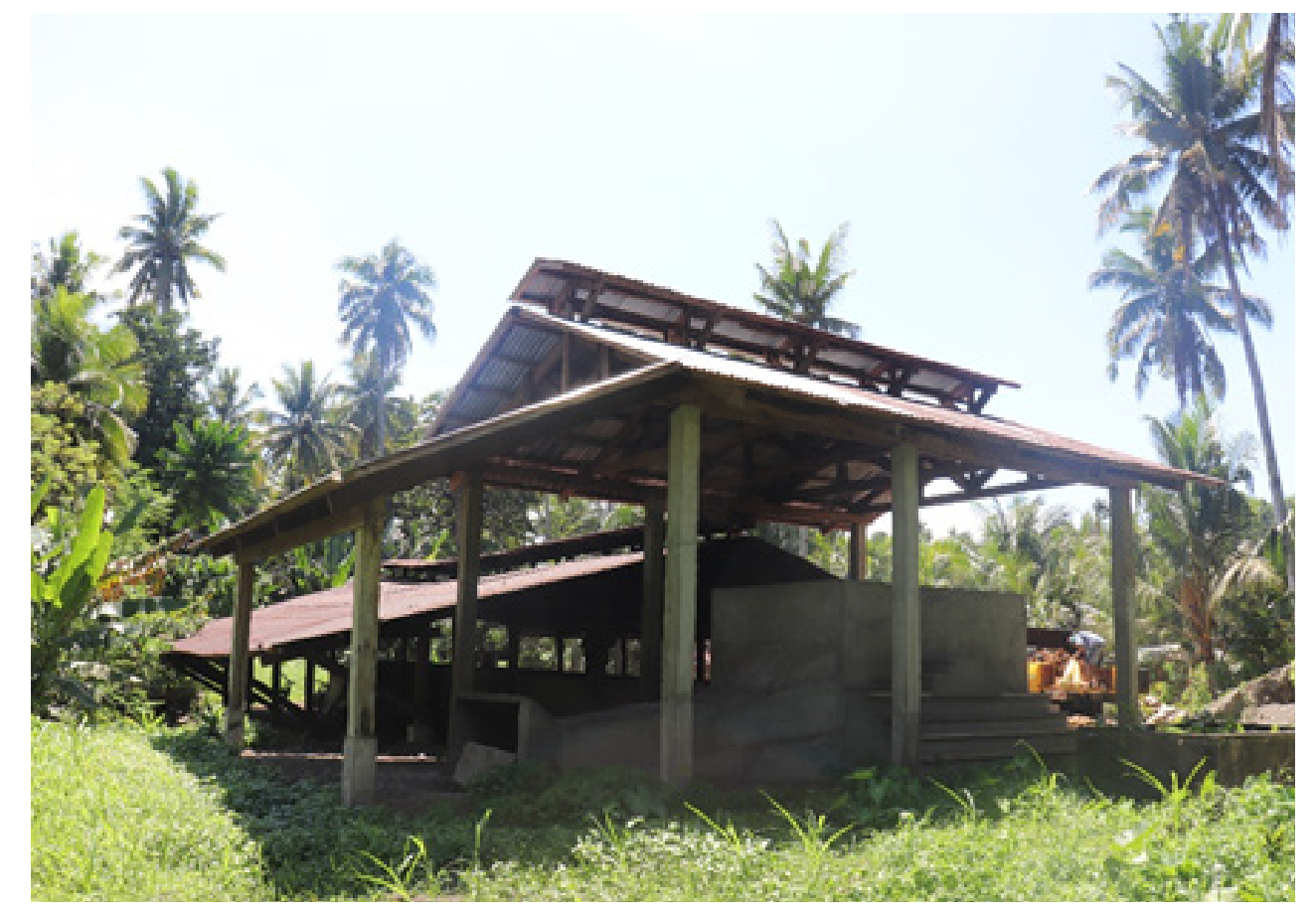

Figure 2. Semi-direct dryer for flat terrain 
size of the tunnel, the air velocity increases thus the hot air could reach the back section of the dryer. The size of the tunnel was then reduced to $55 \mathrm{~cm} \times 55 \mathrm{~cm}$ with a length of $260 \mathrm{~cm}$ and the remaining $40 \mathrm{~cm}$ was the enlarged cross section as shown in Figure 1. Reducing the tunnel size further would cause difficulty in maintaining the tunnel. The dryer was tested again with the modification. Result of the test revealed that the heat distribution on the different sections of the drying platform was comparatively equal with a temperature difference of $2^{\circ} \mathrm{C}$ to $3^{\circ} \mathrm{C}$.

\section{Performance of the Semi-direct Dryer}

The average drying temperatures on the drying platform were $56.5^{\circ} \mathrm{C}, 58.2^{\circ} \mathrm{C}$, and $58.4^{\circ} \mathrm{C}$, on the front, middle and back portion, respectively. Figure 3 illustrates the mean temperature generated during drying. Table 1 shows the average temperature on the different portions of the dryer and the ambient temperature. Result of the one-way analysis of variance revealed that there are no significant differences of the temperature on the different portion of the dryer. The temperature at the

\begin{tabular}{lcccc}
\hline & \multicolumn{3}{c}{ Replication } & Mean \\
\cline { 2 - 4 } & $\mathbf{1}$ & $\mathbf{2}$ & $\mathbf{3}$ & \\
\hline Front & 55.70 & 56.60 & 57.20 & $56.50 \mathrm{a}$ \\
Middle & 57.90 & 57.70 & 59.00 & $58.20 \mathrm{a}$ \\
Rear & 58.20 & 57.60 & 59.40 & $58.40 \mathrm{a}$ \\
\hline
\end{tabular}

*Means having the same letters are not significantly different from each other at $5 \%$ level

Table 1 . Average temperature $\left({ }^{\circ} \mathrm{C}\right)$ of the different portions on the drying platform front, middle, and back portions of the drying platform were comparatively equal. The average drying time to bring down the moisture content from $50 \%$ to $12 \%$ was 24 hours using $66.30 \%$ of the 2,000 coconut husks. Figure 4 shows the drying curve of the copra. Sudaria (1993) reported that the existing semi-direct dryer has an average drying time of 23 hours to bring down the moisture content from $50 \%$ to $12 \%$ using $62.15 \%$ of the 2,000 coconut husks.

\section{Drying Efficiency of the Semi-direct Dryer}

The estimated thermal efficiency of the semi-direct dryer calculated using equation 1 was $12.6 \%$ to $14.3 \%$. The existing dryers specifically the "tapahan" and modified kukum dryer have a thermal efficiency of $12.7 \%$ while the COCOPUGON dryer has a thermal efficiency of 15\% (Dippon and Villaruel, 1996).

\section{Appearance of the Copra}

The color of the copra ranged from light to dark brown as shown in Figure 5. The appearance of the copra was similar to the copra produced by the existing semi-direct dryer.

\section{Break-even Cost Analysis}

The factors considered in getting the BEC were the cost of the structure, labor and the output of the dryer. The total cost of the structure (including the shed) and labor as of October 2020 was P $62,000.00$. The total weight of the copra produced from 2,000 nuts was $504 \mathrm{~kg}$. The computed break-even cost of the dryer was P 1.82/ $\mathrm{kg}$ copra. The break-even cost of the existing semidirect dryer and "tapahan" dryer ranges from $\mathrm{P}$ $0.60 / \mathrm{kg}$ to $\mathrm{P} 1.00 / \mathrm{kg}$. Though the break-even cost



Figure 3. Drying temperature of the dryer

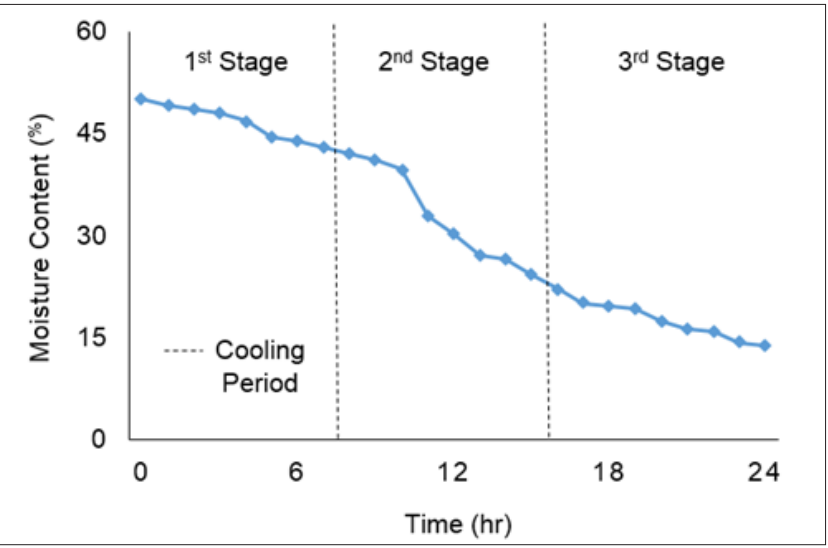

Figure 4. Drying curve 


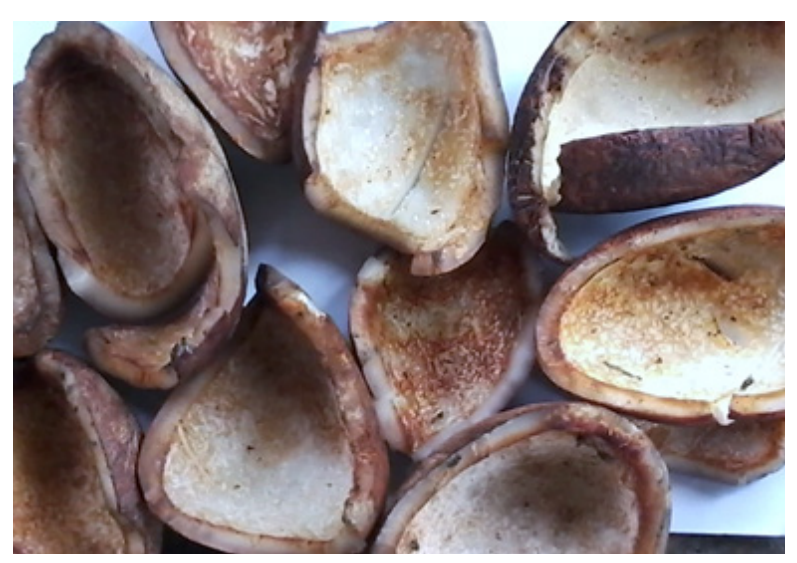

Figure 5. Appearance of the copra

of the existing dryer is lower than the new drier, when considering the life span of new drier, it has added advantage for the processors.

\section{Summary, Conclusion and Recommendation}

The study was conducted to design and develop a semi-direct dryer for flat terrain. Specifically, it aimed to design and construct a semi-direct dryer for flat terrain, to evaluate the performance of the dryer and to determine the breakeven cost of the dryer.

The components of the dryer were the drying bed, plenum chamber, tunnel and firing chamber. It had a capacity of 2,000 coconuts. The fuel used was the husk from the dried coconuts. The means of the average drying temperature on the front, middle and rear portions of the drying platform were $56.5^{\circ} \mathrm{C}, 58.2^{\circ} \mathrm{C}$, and $58.4^{\circ} \mathrm{C}$, respectively. The average time required to bring down the meat moisture content from $50 \%$ to $12 \%$ was 24 hours using $66.30 \%$ of the coconut husks. The estimated drying efficiency was $12.6 \%$ to $14.3 \%$. The total cost of the materials was P $62,000.00$ with a computed break-even cost of $P 1.82 / \mathrm{kg}$ of copra. The color of the copra ranged from light to dark brown. The performance of the dryer was comparable to the existing dryers. It is recommended as an alternative to traditional and existing dryers, particularly the semi-direct and indirect dryers.

\section{References}

De Castro, M. M. 1978. Preliminary Results of the "Kukum" (Modified) Hot-Air Copra Dryer at the Davao Research Center. April, 1978. Diliman, Quezon City, pp. 45.

Dippon, C., and R. Villaruel. 1996. Copra dryers and copra drying technologies. In: Proceeding of the 33rd COCOTECH Meeting, pp.79106. Kuala Lumpur, Malaysia: Asia Pacific Coconut Community (APCC).

Dumaluan, D. L. 1979. Drying Characteristics of Coconut Meat. M.S. thesis. University of the Philippines at Los Banos. Laguna.

Escalante, M. C., J. R. Rosillo, and H. C. Celino. 1977. Coconut Drying Central Pilot Studies (Phase One). Terminal Report. PCRDFFunded Research Project. Department of Agricultural Engineering and Applied Mathematics. VISCA, Baybay, Leyte.

Guarte, R. C., W. Mfihlbauer, M. Kellert. 1996. Drying characteristics of copra and quality of copra and coconut oil. Postharvest and Biology Technology., 9(3): 361-372

Henderson, S.M. and R.L. Perry. 1976. Agricultural Process Engineering. $3^{\text {rd }}$ edition. The Avi Publishing Company, Inc. Westport, Connecticut. pp. 144-145.

Lozada, E. P., J. B. Benico, and V. R. Hao Chin. 1988. The Aflatoxin Problem: The driving force to improve Productivity of the coconut Industry. Proceedings of the $2^{\text {nd }}$ National Coconut week Symposium on "The Coconut Farmers: A Look into the future". PCA Auditorium, Diliman, Quezon City.

Lozada, P. E. 1987. The Los Banos Multi Crop Dryer. Philippine Coconut Research and Development Foundation, Inc. Quezon City, Philippines.

Ly, T. and E. A. Hinay. 1979. Copra Drying. In Comparison Between the Recommended Practice and Farmers' Practice of Splitted Nut Arrangement Before Drying. Annals of Tropical Research, 1(2): 75-81.

Raghavan, K. 2010. Biofuels from Coconuts. http://www.factfoundation.com/en/

Sudaria, E. E. 1993. Design and Development of Semidirect Type Copra Dryer. Coconut Research and Development Journal. Asian and Pacific Coconut Community. Vol. 1 X No. 1.

Woodroof, J. G. 1970. Coconuts: Production, Processing, Products. AVI Publishing Company. The University of Wisconsin - Madison. 


\title{
Evaluation of Nutritional Composition of Defatted Coconut Flour Incorporated Biscuits
}

\author{
H.P.D.T. Hewa Pathirana ${ }^{1}$, W.M.K. Lakdusinghe ${ }^{1}$, L.L.W.C. Yalegama ${ }^{1}$, C.A.T.D. Chandrapeli ${ }^{1}$ \\ and J.A.D Madusanka ${ }^{1}$
}

\begin{abstract}
Defatted coconut kernel is the major by-product of the dry method of virgin coconut oil (VCO) processing which includes high fiber content. It is ground into a fine powder, has a high potential to use as a composite matrix for baked food items with wheat flour. The aim of this research is to compare nutritional characteristics of defatted coconut flour incorporated biscuits (CF), desiccated coconut incorporated commercial biscuits (DC) and wheat flour-based commercial biscuits (WF) using white bread (WB) as a reference. Proximate composition (moisture, ash, crude fat, crude protein, crude fiber and carbohydrate), Hydrolysis Index (HI) and Predicted Glycemic Index (PGI) of samples were performed through standard in-vitro analysis methods. Results of the proximate analysis revealed that moisture $(36.67 \pm 0.16 \%)$ and protein $(13.35 \pm 1.17 \%)$ content of bread were significantly $(\mathrm{p}<0.05)$ higher while fat, fiber and ash content of CF incorporated biscuits were significantly $(\mathrm{p}<0.05)$ higher with the values of $26.67 \pm 1.87 \%, 3.53 \pm 0.10 \%$ and $4.70 \pm 2.61 \%$ respectively. Free sugar glucose content (FSG) of WF was observed the highest significant $(\mathrm{p}<0.05)$ value of $5.88 \pm 1.03 \%$ while the highest amount of rapidly available glucose (RAG) (81.45 $\pm 5.27 \%)$, slowly available glucose (SAG) $(59.81 \pm 7.58 \%)$, total glucose (TG) $(99.16 \pm 5.56 \%)$ were observed in reference food of bread. The PGI of three biscuit types belonging to the medium glycemic food with the values of $60.84,64.53$ and 62.90 respectively for CF, DC and WF treatments.
\end{abstract}

Key words: Biscuits, defatted coconut flour, glycemic index, in-vitro digestion

\section{Introduction}

Coconut (Cocos nucifera) is a widely used raw material in food preparation especially in tropical countries. It is rich in nutrients such as fiber, saturated fat, protein, carbohydrates and minerals such as sodium, potassium, calcium and magnesium. Virgin coconut oil is one of the most valuable products which is extracted from fresh coconut meat without brown testa (paring) with low temperature (dry extraction cold-press process) or without the use of heat (wet extraction process) (Thaiphanit and Anprung, 2016). Consumption of medium-chain fatty acid (MCFA) such as VCO reduces the risk factor of cardiovascular diseases (Oh K et al., 2005), lowers the blood pressure (Nurul-Iman et al., 2013) and blood sugar (Babayan, 1987). The MCFA presents in the VCO can be acted as an energy source for the brain through metabolizing it into the ketone bodies which are converted to acetyl Co-A to produce ATP and it acts as precursors for acetylcholine in neurons (John et al., 2020). Moreover, pure coconut scent is preserved in VCO with a high level of antioxidants and vitamins to improve the anti-carcinogenic activity of the human body (Nevin and Rajamohan, 2004). During virgin coconut oil production defatted edible solid by-product is removed and which is called defatted coconut residue or oil cake ("poonac, Punnakku") can be milled into flour. The coconut flour can provide a nutritious and healthy source of dietary fiber. Trinidad et al (2003) reported that coconut flour plays a role in controlling cholesterol and sugar levels in the blood and in prevention of colon cancer.

Consumption of food with high fiber is very essential for safeguarding from prevalent noncommunicable diseases such as elevated cholesterol, diabetic and cancer. Therefore, people more concern about the ingredients in their diet especially low sugar and high fiber. However, fast-moving lifestyle accelerates fast food consumption such as biscuits, cake and other bakery products. The demands of these types of products are increased because of less perishability, durability, and easy handling than high perishable foods.

\footnotetext{
${ }^{1}$ Coconut Processing Research Division, Coconut Research Institute, Sri Lanka
} 
Most of the fast foods are made of wheat (Triticum aestivum L.) flour. Wheat flour contains $78.10 \%$ carbohydrates, $2.10 \%$ fat, $2.10 \%$ minerals, $14.7 \%$ protein. The quality of wheat flour-based food is high due to the presence of wheat protein gluten (Okpala and Egwu, 2015). Ingredients that are added to the biscuit and processing method can alter the nutritional composition of the final biscuit. Defatted coconut flour is a fiber-rich ingredient and it can alter the nutritional composition of the product compared to the traditional wheat flour-based product. Therefore, Glycemic Index food which is an important characteristic can be altered by the substitution of wheat flour with defatted coconut flour.

Glycemic Index (GI) is defined as the incremental area under the $\beta$-glucose response curve (IAUC) of a tested meal containing $50 \mathrm{~g}$ of digestible carbohydrates and the incremental area under the $\beta$-glucose response curve of the standard food (50 g pure glucose) (IAUCS) (Rudolf et al., 2004). Diet with high GI causes elevated blood glucose level and such food has been associated with the risk of chronic heart diseases. Therefore, the identification of the glycemic index of a food is very crucial for diet management. Generally, the GI of food is determined by in-vivo clinical studies even though it is a time and money-consuming method. However, to predict the GI of a food product through in-vitro digestion that occurs in the upper gastrointestinal tract of humans is used as a promising alternative for clinical GI measurement (Woolnough et al., 2008). The aim of this research is to determine nutritional composition and prediction of the glycemic index (PGI) of defatted coconut flour incorporated biscuits the same as to desiccated coconut incorporated commercial biscuits and wheat flour-based commercial biscuits with reference to white bread through in-vitro analysis.

\section{Materials and Methods}

\section{Materials}

Defatted coconut flour added biscuits (CF) were prepared in Coconut Processing Research Division at Coconut Research Institute, Sri Lanka. The desiccated coconut added biscuit (DC), wheat flour added biscuit (WF) and white bread (BR) as a reference were purchased from the Cargill Food City supermarket at Dankotuwa, Sri Lanka. The enzyme of pepsin, amyloglucosidase, invertase and pancreatin were purchased from sigma. The poly propylene tubes (50 ml), Fan forced Oven (JEIO TECH (OF - 22G), Analytical balance (OHAUS), Randall hot extraction apparatus (Behr E 6), FIWE extraction unit, Shaking water bath (SWBR17-2), Spectrophotometer (UV-1800 Shimadzu) were used.

\section{Methods}

\section{Preparation of defatted coconut flour-based biscuit}

A dough of biscuits was prepared by mixing $300 \mathrm{~g}$ defatted coconut flour and 700 $\mathrm{g}$ wheat flour as the main matrix for biscuits development. Other ingredients: baking powder (20 g), margarine (600 g), sugar (500 $\mathrm{g})$, egg (50 g) and salt ( $5 \mathrm{~g}$ ) was measured and mixed well in a bowl in a machine of dough mixture (model- Sherry $8 \mathrm{p}-800$ ) in 20 min. Then the dough was leveled by a roller and was cut using a mold of circular shape (diameter $2 \mathrm{~cm}$ ) and placed on an oil paper in a stainless-steel tray. The biscuits were baked for 15 minutes at $160 \mathrm{oC}$ in a pre-heated oven and were allowed for cooling and were packed in triple laminated aluminum pouches.

\section{Proximate composition}

The proximate composition (moisture, ash, crude fat, crude protein, crude fiber and carbohydrate) of four samples was determined (AOAC, 2005) with four replicates.

\section{In-vitro measurement of different sugar fractions}

Free sugar glucose (FSG) contents of each biscuit were determined by Nani et al. (2017) method. Biscuit samples with $0.5 \mathrm{~g}$ carbohydrate were placed in a polypropylene tubes and $5 \mathrm{ml}$ of $0.5 \mathrm{M}$ sodium acetate buffer (pH 5.2) were added. The contents were shaken well. The samples were incubated at $100 \mathrm{oC}$ in a boiling water bath for 30 minutes and cooled to room temperature. The glucose contents of the samples were measured by using a glucose determination kit (GOD PAP, France). GI of three biscuit samples with reference to white bread were determined according to Englyst's protocol with modifications (Englyst et al., 1995). Minced biscuit with $0.5 \mathrm{~g}$ carbohydrate was placed in polypropylene tubes and were subjected to a mixture of enzymatic digestion with mechanical disruption by small glass balls. Then, samples were incubated at $37^{\circ} \mathrm{C}$ in a shaking water bath to continue the hydrolysis and $1 \mathrm{ml}$ of samples 


\begin{tabular}{ccccccc}
\hline Treatments & Moisture (\%) & Protein (\%) & Crude Fat (\%) & Ash (\%) & Crude Fiber (\%) & Carbohydrate (\%) \\
\hline BR & $36.67 \pm 0.16 \mathrm{a}$ & $13.35 \pm 1.17 \mathrm{a}$ & $2.60 \pm 0.11 \mathrm{~d}$ & $2.43 \pm 0.12 \mathrm{~b}$ & $0.28 \pm 0.09 \mathrm{c}$ & $44.67 \pm 1.34 \mathrm{~d}$ \\
CF & $3.04 \pm 0.08 \mathrm{~b}$ & $3.67 \pm 0.21 \mathrm{c}$ & $25.67 \pm 1.87 \mathrm{a}$ & $3.53 \pm 0.10 \mathrm{a}$ & $4.70 \pm 2.61 \mathrm{a}$ & $59.40 \pm 3.75 \mathrm{c}$ \\
DC & $0.89 \pm 0.08 \mathrm{~d}$ & $4.76 \pm 0.42 \mathrm{~b}$ & $18.21 \pm 0.15 \mathrm{~b}$ & $1.65 \pm 0.20 \mathrm{~d}$ & $3.08 \pm 0.22 \mathrm{ab}$ & $71.42 \pm 0.86 \mathrm{~b}$ \\
WF & $2.28 \pm 0.11 \mathrm{c}$ & $4.71 \pm 0.38 \mathrm{~b}$ & $11.24 \pm 1.44 \mathrm{c}$ & $2.04 \pm 0.20 \mathrm{c}$ & $1.46 \pm 0.57 \mathrm{bc}$ & $78.28 \pm 0.92 \mathrm{a}$ \\
\hline
\end{tabular}

Table 1. Proximate composition of resulted biscuits, commercial biscuits and white bread

Values are Means \pm standard deviations and different superscripts in the same column are significantly different ( $\mathrm{p}<0.05)$, BR: White bread, CF: Defatted coconut flour-based biscuits, DC: Desiccated coconut added biscuits, WF: Wheat flour-based biscuits.

were taken from each treatment at certain time intervals $(0,20,30,60,90$ and 120 minutes) to determine the glucose content. The glucose content of sample after 20 min was measured as G20 - Rapidly Available Glucose (RAG) and glucose content of the sample after $120 \mathrm{~min}$ of digestion was designated as G120 - Slowly Available Glucose (SAG). After 120 min, the remaining samples were treated with additional enzymes and the temperature was increased to $100{ }^{\circ} \mathrm{C}$ to complete the hydrolysis followed by centrifuging at $1500 \mathrm{xg}$ for $2 \mathrm{~min}$ to obtain a clear supernatant and thus, Total Glucose Content (TGC) of the samples were determined. To measure the glucose content at each time for specific digestion, an aliquot of $(200 \mu \mathrm{l})$ of the sample was mixed with $4 \mathrm{ml}$ of absolute ethanol to stop the hydrolysis. Glucose content of the sample was determined using a glucose determination kit (GOD PAP, France) based on the procedure given by the GOD, PAP, France and the absorbance was measured at $505 \mathrm{~nm}$ using a spectrophotometer (UV-1800 Shimadzu).

\section{Calculations and statistics}

RAG, SAG and various starch fractions were calculated by using the following equations.

$$
\begin{aligned}
& \text { 1-Rapidly Available Glucose (RAG) = G20 } \\
& \text { 2-Slowly Available Glucose (SAG) = G120 - G20 } \\
& \text { 3- Free Sugar Glucose (FSG) = G30 }
\end{aligned}
$$

The results were converted to starch by multiplying the percentage glucose concentration by a factor (0.9). Then percentages of starch hydrolysis were built for each sample and reference food over the incubation time. The area below the hydrolysis curve (AHC) was estimated by integrating the hydrolysis curves.
The Hydrolysis Index (HI) was calculated as the ratio between the AHC of each sample and the AHC of glucose and expressed as a percentage. The GI of the samples were estimated according to the equation of GI $=39.71+0.549 \mathrm{HI}$ (Goni et al., 1997). Statistical analysis (ANOVA) was performed using the MINI TAB system (Version 16.0). Tukey's tests were used for comparison of means at $\mathrm{p}<0.05$.

\section{Results and Discussion}

The results of proximate composition show significant differences for moisture, protein, crude fat, ash, crude fibre and carbohydrates contents of biscuits (Table 1).

\section{Moisture}

The moisture content of food indicates the water activity which is responsible for the shelf-life stability of processed food. Adding more water into the dough of bread increases the water content of bread to increase the bread yield and profit (Miller et al., 2008). That's why bread has significantly $(\mathrm{p}<0.05)$ higher moisture content $(36.67 \pm 0.16 \%)$ compared to the three types of biscuits (Table 1). Results showed that CF has significantly $(\mathrm{p}<0.05)$ higher moisture content $(3.04 \pm 0.08 \%)$ than DC $(0.89 \pm 0.08 \%)$ and WF $(2.28 \pm 0.11 \%)$ biscuits samples. The reason may be due to the high water absorption ability of coconut flour.

\section{Protein}

Proteins are essential macromolecules for the development of biological organs. Amino acids are monomers of the protein molecules. The BR has significantly higher protein content $(13.35 \pm 1.17 \%)$ (Table 1$)$. The protein content of DC $(4.76 \pm 0.42 \%)$ and WF $(4.71 \pm 0.38 \%)$ is 
significantly $(\mathrm{p}<0.05)$ the same while CF shows a significantly low protein content $(3.67 \pm 0.21$ $\%$ ). Thirty percent substitution of wheat flour from defatted coconut flour did not affect the increment of protein percentage in defatted coconut flour added biscuits even defatted flour has a higher protein content of $21.76 \%$ (Yalegama et al., 2013).

\section{Fat}

The fat content of food provides energy and essential fatty acids to boost the body function. Source of fat (Animal or plant origin) determine the health aspects of human while creating non-communicable diseases such as elevated cholesterol and heart diseases (Zheng F. M. and Yeong Y.L, 2016). Coconut flour contains significantly high fat content $(13.43 \%)$ compared to wheat flour (1.93 \%) (Yalegama et al, 2013). The CF has a significantly higher fat content $25.67 \pm 1.87 \%$ than DC treatment (Table 1). The raw material of desiccated coconut contains $68 \%$ (SLSI, 98) of fat which is higher than the fat content of coconut flour (13.43\%). Even desiccated coconut added biscuit is expected to have higher fat content. The amount of replacement of wheat flour from desiccated coconut or defatted coconut flour is a critical factor to change the nutritional profile of biscuits.

\section{Ash}

Ash content of the food gives an overview of the mineral content. Fortification of mineral substances to the food product is a novel trend to boost the nutrient content of food while acquiring health benefits for human life. Previous studies showed that wheat flour is less in ash with the approximate figures of $0.70 \%$ (Ocheme et al., 2018). In contrast, coconut flour contains five times higher minerals (5.12\%) (Yalegama et al, 2013) than wheat flour (0.7\%) (Ocheme et al., 2018). Therefore, the biscuits substituted with defatted coconut flour have a significantly higher mineral content $3.53 \pm 0.10$ $\%$ (CF) than the wheat flour-based biscuits.

\section{Crude Fiber}

Crude fiber is the carbohydrate substances that our bodies cannot digest. Insoluble fiber after the digestion acts like a broom to sweep out the digestive tract while preventing constipation, infections of the gut, hemorrhoids, heart disease and some types of cancer. Therefore, consumption of fiber-rich food is very vital to boost the healthy life of a human. Defatted coconut flour contents (9.27 $\%)$ of crude fiber (Yalegama et al., 2013) are higher than wheat flour $(0.84 \%)$ (Ocheme et al., 2018). Therefore, significantly higher crude fiber content was observed in the CF $(4.70 \pm 2.61$ $\%)$ and DC $(3.08 \pm 0.22 \%)$ treatments. As crude fiber does not contribute to energy, it is expected not to contribute to a high glycemic index. So, the biscuit with high fiber content is expected to show a lower GI value.

\section{Carbohydrate}

The carbohydrate content of the sample includes the sugar and starch material which are incorporated in the food products. The sugar content of food directly contributes to the Glycemic Index of the food to categorize it as a product of low, medium or high Glycemic. Defatted coconut flour contains $46.73 \%$ (Yalegama et al., 2013) carbohydrate content which is significantly lower compared to the wheat flour having carbohydrate content of $72.73 \%$ (Ocheme et al., 2018). Results revealed that wheat flour added biscuits (WF) have the highest carbohydrate content $(78.28 \pm 0.92 \%)$ in a fresh sample. Desiccated coconut incorporated biscuit (DC) had 71.42 $\pm 0.86 \%$ carbohydrate content which is significantly lower than WF. CF has the lowest carbohydrate content $(59.40$ $\pm 3.75 \%$ ) out of three types of biscuits varieties.

\section{In-vitro measurement of different sugar fractions}

The results are shown in Table 2.

\section{Free sugar glucose content of the food product}

Dietary carbohydrates are absorbed into small intestine depending on the source, physicho- chemical properties and processing aspects of the food product. Free glucose in the food is freely attached to mono and disaccharides and their alcohol substances which undergo the immediate release of glucose molecules into the intestine after the ingestion of food. A significantly higher level of free sugar glucose (sum of free glucose and glucose from sucrose) has in WF $(5.88 \pm 1.03 \%)$ than others. 


\begin{tabular}{ccccccc}
\hline Treatments & FSG & RAG & SAG & TG & HI & PGI \\
\hline BR & $0.45 \pm 0.17 \mathrm{~b}$ & $81.45 \pm 5.27 \mathrm{a}$ & $59.81 \pm 7.58 \mathrm{a}$ & $99.16 \pm 5.56 \mathrm{a}$ & - & - \\
CF & $0.79 \pm 0.50 \mathrm{~b}$ & $35.10 \pm 2.96 \mathrm{~b}$ & $36.18 \pm 5.53 \mathrm{~b}$ & $40.91 \pm 1.34 \mathrm{c}$ & 38.58 & 60.84 \\
DC & $0.20 \pm 0.03 \mathrm{~b}$ & $21.72 \pm 4.65 \mathrm{c}$ & $33.97 \pm 4.82 \mathrm{~b}$ & $54.40 \pm 8.21 \mathrm{~b}$ & 45.31 & 64.53 \\
WF & $5.88 \pm 1.03 \mathrm{a}$ & $38.20 \pm 5.10 \mathrm{~b}$ & $41.11 \pm 2.68 \mathrm{~b}$ & $45.84 \pm 5.60 \mathrm{bc}$ & 42.35 & 62.91 \\
\hline
\end{tabular}

Table 2. Glucose concentrations of four biscuits after in-vitro digestion

Values are Means \pm standard deviations and different superscripts in the same column are significantly different $(\mathrm{p}<0.05)$, BR: White bread, CF: Defatted coconut flour-based biscuits, DC: Desiccated coconut added biscuits, WF: Wheat flour-based biscuits.

\section{Rapidly available glucose content of the food product}

Glucose which is released after 20 min of digestion helps to surge the blood sugar level after food consumption. Glucose is an important source of energy for almost all the cells in the body, especially the brain cells. Therefore, athletes may use glucose as their energy source, thus it rapidly releases the highest concentration of glucose within a shorter period of time. Results of this study revealed that significantly $(\mathrm{P}<0.05)$ higher level of rapidly available glucose $(81.45 \pm 5.27 \%)$ is released by BR within the in-vitro digestion system. Therefore, consumption of food with elevated rapidly available glucose such as white bread is not recommended for diabetic patients.

\section{Slowly available glucose and total glucose content}

Slowly releasing glucose-containing food is good for maintaining proper blood sugar status within the human system. White bread had a significantly higher slowly available glucose content of $59.81 \pm 7.58 \%$ compared with other biscuit types. However, there were no significant effects of the incorporation of defatted coconut flour into biscuits because all the biscuit samples used for this study had similar slowly available glucose contents. However, the formula can be improved to have the desired effect.

The in-vitro system, complete hydrolysis with an excess amount of enzyme is carried out to release all the glucose to the system. Excess enzymes removed a significantly higher amount of total glucose $(99.16 \pm 5.56 \%)$ in the BR sample while lower releasing with CF $(40.91 \pm 1.34 \%)$. Therefore, these values are expected to show a lower GI value.

\section{Hydrolysis index and predicted glycemic index of biscuits}

Glycemic Index of food sample provides an overview of glucose absorption into the small intestine. The calculated hydrolysis indexes for CF, DC and WF are 38.58, 45.31 and: 42.35 respectively. When the value of the glycemic index is less than 55 , it is considered as a low GI food and the value is between 55 to 70 is considered as medium GI food and more than $70 \mathrm{GI}$ value is considered as a high GI food (Eleazu, 2016). The lowest PGI value has been observed in the CF sample and it has 60.84 whereas can be ranked as medium GI food. Thus, coconut flour has a substantial effect on the digestion of the in-vitro system by delaying glucose releasing to the outer environment from the food. It can be due to the significant proportion of ash and fiber content of the defatted coconut flour incorporated biscuits. The starch releasing ability of three samples and white bread revealed that the starch releasing ability of CF is low while the highest starch releasing ability in WF (Figure 1).

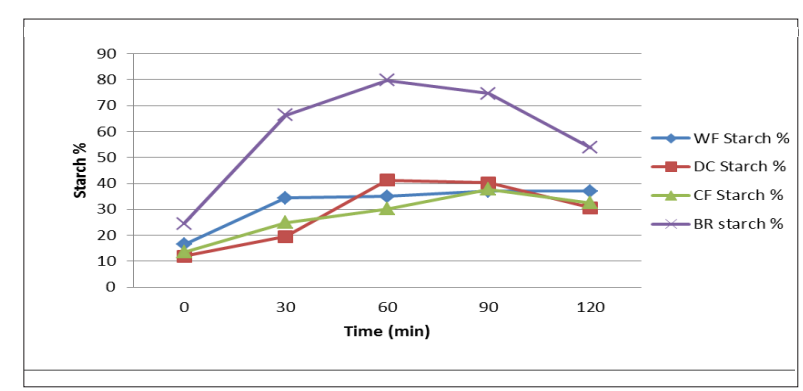

Figure 1. Starch concentration (\%) of each sample during in-vitro digestionin-vitro digestion 
Incorporation of defatted coconut flour increased the fiber and ash content of the biscuits while reducing sugar releasing capacity after in-vitro digestion. Therefore, it reduces the Glycemic Index of the product than the wheat flour-based counterparts. The defatted coconut flour-based biscuits (CF), as well as desiccated coconut incorporated (DC) and wheat flourbased biscuits (WF) can be categorized as medium GI food which is a healthy diet for a diabetic person and those who searching for healthy diets.

\section{References}

AOAC International 2005.0fficial Methods of Analysis of AOAC International, $18^{\text {th }}$ edition. AOAC International, Rockville, Maryland, USA.

Babayan, V. K. 1987. Medium-chain triglycerides and structured lipids. Journal of Lipids, 22: 417-420.

Eleazu, C. O. 2016. The concept of low glycemic index and glycemic load foods as panacea for type 2 diabetes mellitus; prospects, challenges and solutions. African Health Sciences, 16 (2): 468- 479.

Englyst, H. N., Quigley, M. E. and Hudson, G. J. 1995. Definition and measurement of dietary fibre. Eur Journal of Clin Nutr., 49: 48-62.

Goni, I., Garcia-Alonso, A. and Saura-Calixto, F. 1997. A starch hydrolysis procedure to estimate glycemic index. Journal of Nutr Res., 17: 427-437.

John, J., Sapa, N. K. R. and Shenoy, R. R. 2020. Virgin coconut oil ameliorates colchicine induced cognitive dysfunction- a preclinical study. Journal of pharmaceutical sciences, 26(1): 1-12.

Miller, R. A., Maningat, C. C. and Hoseney, R. C. 2008. Modified wheat starches increase bread yield. J. Cereal Chemistry, 85(6): 713-715.

Nani, R., Suparmo, Eni H. and Yustinus, M. 2017. In vitro starch digestibility and estimated glycemic index of Indonesian cowpea starch (Vignaunguiculata). Pakistan Journal of Nutrition, 16: 1-8.

Nevin, K. G. and Rajamohan, T. 2004. Beneficial effects of virgin coconut oil on lipid parameters and in vitro LDL oxidation. Journal of clinical biochemistry, 37: 830-835.

Nurul-Iman, B. S., Kamisah, Y., Jaarin, K. and Qodriyah, H. M. S. 2013. Virgin coconut oil prevents blood pressure elevation and improves endothelial functions in rats fed with repeatedly heated palm oil. Journal of Evidence-based Complementary and Alternative Medicine, 1-7.

Ocheme, O. B., Adedeji, O. E., Chinma, C. E., Yakubu, C. M. and Ajibo, U. H. 2018. Proximate composition, functional, and pasting properties of wheat and groundnut protein concentrate flour blends. Food Sci Nutr, 6: 1173- 1178.

Oh, K., Hu, F. B., Manson, J. E., Stampfer, M. J. and Willett, W. C. 2005. Dietary fat intake and risk of coronary heart disease in women: 20 years of follow-up of the nurses' health study. American Journal of Epidemiology, 161: 672-679.

Okpala, L. C. and Egwu, P. N. 2015. Utilization of broken rice and cocoyam flour blends in the production of biscuits. Nigerian Food Journal, 33(1): 8-11.

Rudolf, C., Bartekb, B., Martina, R., Jana, Z., Blanka, D., Ludmila, C., Pavel, S., Svatava, D. and Vilím, S. 2004. Determination of the glycaemic index of selected foods (white bread and cereal bars) in healthy persons. Biomed, 148(1): 17-25.

SLSI 98, (1988). Sri Lanka Standard Specification for Desiccated coconut, first edition, Sri Lanka Standard Institution, Colombo.

Thaiphanit, S. and Anprung, P. 2016. Physicochemical and emulsion properties of edible protein concentrate from coconut (Cocos nucifera L.) processing by-products and the influence of heat treatment. Food Hydrocolloids, 52: 756-765.

Trinidad, P. T., Divinagracia, H. V., Anacleta, S. L., Aida, C. M., Faridah, C. A., Joan, C. C. and Dina, B. M. 2003. Glycaemic index of different coconut (Cocos nucifera)-flour products in normal and diabetic subjects. British Journal of Nutrition, 90: 551-556.

Woolnough, J. W., Monro, J. A., Brennan, C. S. 
and Bird, A. R. 2008. Simulating human carbohydrate digestion in vitro: A review of methods and the need for standardization. Int. J. Food Sci. Technol, 43: 2245-2256.

Yalegama, L.L.W.C, Karunaratne, D.N., Sivakanesan, R. and Jayasekara, C. 2013. Chemical and functional properties of fibre concentrates obtained from by-products of coconut kernel. Food Chemistry, 141: 124-130.

Zheng, F. M, and Yeong, Y. L. 2016. Virgin Coconut Oil and its Cardiovascular Health Benefits. Natural Product Communications, 11: 8. 